\title{
Universal Human Rights and the Coloniality of Race in Sweden
}

\author{
Michael McEachrane ${ }^{1}$ (D)
}

Published online: 13 April 2018

(C) The Author(s) 2018

\begin{abstract}
This article makes an argument that using the term race and considering structural racial discrimination as such and the impacts on it of European colonialism are needed for Sweden's observance of universal human rights. This argument is contrary to the view of the Swedish state and challenges an image of Sweden as a champion for universal human rights without any colonial history or racial problems of its own.
\end{abstract}

Keywords Sweden $\cdot$ Race $\cdot$ Colonialism $\cdot$ Universal human rights $\cdot$ CERD

How, if at all, are race, structural racial discrimination, and European colonialism relevant to the observance of universal human rights in Sweden? Some social scientists would argue that there is a widespread denial in today's Europe that race and colonialism are politically relevant (Bonilla-Silva 2000, 2006; Gilroy 2005; Goldberg 2009; Shilliam 2017). Sweden may be put forth as a special case in this regard. Post-WWII Sweden has made itself known as a prominent defender of universal human rights. It has actively supported struggles against colonialism and apartheid, the selfdetermination and development of Third World countries, been an outspoken critic of racism and imperialism, and among the most generous developed countries toward refugees. Until recently, it has positioned itself as without any colonial history. Neither has post-WWII Sweden recognized race as a social problem in the country, and since 2009, it has even banished the term race from its antidiscrimination law.

This article argues that using the term race and considering structural racial discrimination and the impacts on it of European colonialism are needed to respect universal human rights in Sweden. By way of examining the use of words such as race, racial discrimination, and colonialism in human rights instruments, laws, state reports, and

Michael McEachrane

michael.mceachrane@ rwi.lu.se

1 Raoul Wallenberg Institute of Human Rights and Humanitarian Law, Lund, Sweden 
other documents - the article offers a series of conceptual investigations into the use of such words as relevant to Sweden's observance of universal human rights (cf. Wittgenstein 2009/1953).

\section{Structural Racial Discrimination and Universal Human Rights}

Among the characteristics that sets the International Convention on the Elimination of All Forms of Racial Discrimination (ICERD) apart from most other antidiscrimination law is that it includes a broad "structural" view of racial discrimination. Article 1.1 of the ICERD defines racial discrimination as

any distinction, exclusion, restriction or preference based on race, colour, descent, or national or ethnic origin which has the purpose or effect of nullifying or impairing the recognition, enjoyment or exercise, on an equal footing, of human rights and fundamental freedoms in the political, economic, social, cultural or any other field of public life. (OHCHR 1965, Art 1.1)

This entails a broader protection against racial discrimination than on an individual and case-by-case basis where members of such groups may be discriminated against in specific situations and incidents such as when applying for a job or in public facilities. It encompasses protection against any form - most notably, recurring and compounded forms - of interpersonal, social, institutional, and other societal "distinction, exclusion, restriction or preference" based on race with "the purpose or effect of nullifying or impairing the recognition, enjoyment or exercise, on an equal footing, of human rights". For example, interpersonal, social, institutional, or other public conditions where people of African descent are more likely than white Europeans to have their equality of rights impaired in employment, housing, education, public spaces, by law enforcement, and so on. The UN Committee on the Elimination of Racial Discrimination (CERD) General Recommendation 14 on how to interpret Article 1.1 of the ICERD - stresses that whatever the reasons for such group differences it is the de facto enjoyment of rights that matters: "A distinction is contrary to the Convention if it has either the purpose or the effect of impairing particular rights and freedoms" (CERD 1993). This sort of broad structural view of racial discrimination and the obligation of states to protect against it is emphasized throughout the ICERD. For instance, in its call on states to "review governmental, national and local policies, and to amend, rescind or nullify any laws and regulations which have the effect of creating or perpetuating racial discrimination wherever it exists"; to take special measures to "ensure the adequate development and protection of certain racial groups or individuals belonging to them for the purpose of guaranteeing them the full and equal enjoyment of human rights"; and in its condemnation of racial segregation and apartheid (OHCHR 1965). The Durban Declaration and Programme of Action (DDPA) takes a similar broad view of racial discrimination - including everything from attitudes, stereotyping, and discrimination against particularly vulnerable groups (such as indigenous peoples, people of African descent, and refugees) to lack of political will (OHCHR 2001). What is more, whereas the articles of the ICERD explicitly limit themselves to national jurisdiction, the DDPA includes international issues such as racial inequities in 
environmental control, migration, trade, and national debt and summons a global fight against racism with measures at the national, regional, and international levels (OHCHR 1965, Art 1.2; 2001).

\section{(Post-)Colonialism and Universal Human Rights}

All three universal human rights instruments on racial discrimination - the ICERD, DDPA, and the Declaration on Race and Racial Prejudice (1978) - as well as the UNESCO Statement on Race and Racial Prejudice (1967), point to connections between European colonialism, its aftermath, and racial discrimination. ${ }^{1}$ The UNESCO Statement points out that, "Many forms of racism have arisen out of the conditions of conquest, out of the justification of Negro slavery and its aftermath of racial inequality in the West, and out of the colonial relationship" (UNESCO 1969, p. 51). The Preamble of the ICERD condemns "colonialism and all practices of segregation and discrimination associated therewith, in whatever form and wherever they exist", and CERD General Recommendation 34 calls on States to acknowledge "the negative effects of the wrongs occasioned on people of African descent in the past, chief among which are colonialism and the transatlantic slave trade" (OHCHR 1965, 2011, §3.17). The Preamble of the Declaration on Race and Racial Prejudice (1978) is mindful that "the process of decolonization" created "new opportunities of eradicating the scourge of racism" while noting "with the gravest concern that racism, racial discrimination, colonialism and apartheid continue to afflict the world in ever-changing forms" (OHCHR 1978). However, it is the DDPA - the world's most comprehensive universal human rights instrument on racial discrimination and second in prominence after the ICERD - that is clearest and most elaborate about the connections between European colonialism and racial discrimination (OHCHR 2001). The DDPA pronounces that,

colonialism has led to racism, racial discrimination, xenophobia and related intolerance, and that Africans and people of African descent, and people of Asian descent and indigenous peoples were victims of colonialism and continue to be victims of its consequences. (OHCHR 2001, art. 14 p. 17)

It regrets "that the effects and persistence of these structures and practices [of European colonialism] have been among the factors contributing to lasting social and economic inequalities in many parts of the world today" (ibid). Among the most egregious aspects of European colonialism - that the DDPA claims are major sources of racism and racial discrimination, and moreover acknowledges as crimes against humanity - are slavery, slave trade, apartheid, and genocide (OHCHR 2001, art. 13 p. 16 , art. 15 p. 17 , art. 28 p. 20). With respect to the massive human suffering caused by slavery, the slave trade, the transatlantic slave trade, apartheid, colonialism, and genocide, the DDPA asserts "the moral obligation on the part of all concerned States and call upon these States to take appropriate and effective measures to halt and reverse

\footnotetext{
${ }^{1}$ I have added "European" to "colonialism" here and elsewhere, not to reduce all colonialism to European colonialism, but to (i) make explicit a reference that often is implicit in universal human rights instruments and (ii) specifically point to connections between structural racial discrimination and European colonialism.
} 
the lasting consequences of those practices" (OHCHR 2001, art. 102 p. 38). Accordingly, the DDPA recognizes the need to create programs for the social and economic development in developing countries and the Diaspora and in areas such as debt relief, poverty eradication, technology transfer, and the facilitation of welcomed return to and resettlement in Africa of the descendants of enslaved Africans (OHCHR 2001, art. 158 pp. 49-50).

Although the DDPA does not explicate exactly how European colonialism is a major culprit of racial discrimination and why it matters - the contours can relatively easily be filled out. In broad strokes, the imposition of European colonialism founded an international order of racial (and ethnic) domination, discrimination, and stratification. A two- (and indeed multi-) tier structure or pattern was established where white Europeans and ethnicities were acceded most dignity and rights, or dignity and rights whatsoever, whereas non-white people and ethnic groups were denied equal dignity and rights or dignity and rights whatsoever. This two-tier structure was established between the colonizers and the colonial subjects - between the metropoles and the colonies, internally in the colonies where Europeans settled and inside the metropoles across areas such as law, politics, culture, education, and conceptions of European civilization, history, and nationhood. Economically, European colonialism sought to control and extract goods, labor, and profits from the human and natural resources of the colonies. Chattel enslavement was part of this two-tier wealth extraction. While conceptions of race and racial difference changed from the beginning of European expansion in the fifteenth century until the end of the colonial era in the twentieth century - indeed the term race itself was not used to describe human groups until in the seventeenth century - in practice as well as in conception the tendency was always to attribute greater worth to white Europeans (cf., e.g., Thornberry 2016; DuBois 2007; Fanon 2004/1963; Mbembe 2017; Mills 1997, 2003, 2017; Go 2011, 2016; McKittrick 2015).

\section{Race and Colonialism in Pre-WWII Sweden}

What we find when studying Sweden as a nation-state prior to WWII is that racial discrimination - as understood by the ICERD and DDPA — was fundamental to it and that Sweden was socially, culturally, politically, legally, and economically organized around race. This seems true both of how Sweden constituted itself at the national level and in international relations. It would seem that pre-WWII Sweden and its place in the world was shaped by the many distinctions, exclusions, restrictions, and preferences between Europeans and non-Europeans - with respect to what we today would recognize as human dignity and rights - that were practised and amassed during the nearly half a millennium long era of colonialism beginning in the late fifteenth century. These colonial era distinctions between Europeans and non-Europeans were based on "race" in the sense that they at a minimum were based on notions of the geographical locations, origins, and physical appearances of peoples - typically coupled with notions of differences in culture, mores, and character. The term race itself, though, and the categorization of humanity into distinct biological types with innate mental and cultural characteristics were not established in Europe until in the eighteenth century (e.g., Hannaford 1996). And even after that, one should carefully examine if and how beliefs 
in innate mental and cultural qualities played a role in practices of discrimination on the grounds of "race" and not assume that they all were based on, depended on, or involved such beliefs.

On a global scale, Sweden was part of, contributed to, and benefited from the shaping of the world of the colonial era around race. This included views and attitudes regarding the superiority to the rest of the world of white Europeans and European civilization; the dismissal and suppression of non-European and indigenous peoples and cultures as heathen, primitive, and undeveloped; the appropriation by Europeans, to their material benefit, of the human and natural resources of non-Europeans; being white as a condition for equal dignity and rights; and the systematic (national and international) subjugation of people of colour and indigenous people to a second class status.

To understand the pre-WWII formation of Swedish nationhood-i.e., the identity of Sweden as a nation and Swedish people as Swedes - it is helpful to distinguish race from ethnicity. The pre-WWII formation of Swedish nationhood was not merely based on notions of ethnicity - for example, that distinguished ethnic Swedes from ethnic Finns, Danes, and Norwegians - but also on notions of race which placed Swedes in a larger European community distinguished from non-Europeans. The pre-WWII Swedish discourse of being part of a European community was primarily based on notions of belonging to an interrelated culture or civilization more broadly - with, say, Christian beliefs and traditions; an intellectual history going back to the Ancient Greeks and Romans; having a share in the high culture and Arts of Europe; being part of transnational scholarly conversations; sharing and exchanging technologies, goods, and services; having similar forms of governance; being part of a European system of sovereign states; and more. However, in line with European discourses around culture, origin, and difference that developed during an age of global exploration and colonization - in Sweden too, ideas of cultural, ethnic, and national character intermingled with ideas of physical, innate, and geographic differences between Europeans and non-Europeans. What ensued was a pre-WWII narrative around Swedish nationhood where the deepest fault-line of cultural and national identity was not ethnicity per se-after all, this separated Swedes from other Europeans - but race (cf., e.g., McEachrane and Faye 2001; Mills 1997, 2017; Keskinen et al. 2009; Loftisdóttir and Jensen 2012; Naum and Nordin 2013; Fur 2013; Weiss 2013, 2015, 2016).

From the eighteenth century until around WWII, it became increasingly common in Sweden to conceive of humanity as divided into racial groups with distinct geographical origins and physical and psychological characteristics. In his magnum opus of modern biological taxonomy Systema Naturae - which went through ten editions between 1735 and 1758 and soon became the standard at all universities in EuropeSwedish botanist Carl Linnaeus (1707-1778) classified Homo sapiens into continentally distinct white (Homo Europaeus), yellow (Homo Asiaticus), red (Homo Americanus), and black (Homo Africanus) varieties with different psychological and cultural characteristics (Eze 1997; Jackson and Weidman 2004, p. 16). Although Linnaeus himself did not use the term race, his continental white-yellow-red-black classification became a point of contention for Comte de Buffon (1707-1708), who did use the term race in the seminal Histoire Naturelle (1749), and was also recognized by pioneering anthropologist, Johann Friedrich Blumenbach (1752-1840), as a novel contribution to the development of racial classification (Jackson and Weidman 2004, pp. 17-18; Hannaford 1996, p. 204). 
From at least the first half of the seventeenth century to the infamous Berlin Conference 1884-1885, Sweden too participated in the European scramble for overseas colonies (Nováky 1990; Nilsson 2013). Like other European countries, Sweden had fleets of chartered African, East Indian, and West Indian Companies. In 1650, the shortlived but prosperous Swedish Africa Company (1649-1663) established a minor trading colony at Cabo Corso in present-day Ghana, where fort Carolusburg (later renamed Cape Coast Castle by the English) was built by enslaved Africans (Nováky 1990). Besides gold, ivory, sugar, and other products, the Company traded in enslaved Africans (ibid). For centuries, plantation sugar was imported to Sweden with refineries being built in Stockholm and Gothenburg in the second half of the seventeenth century. In 1738, Swedes consumed 450 tons of sugar per year which alone required the labor of some 500 enslaved adults, and by the middle of the nineteenth century, Swedish sugar consumption alone required the labor of at least 15,000 enslaved adults annuallyapproximately the same number of people living in quite large Swedish cities at that time such as Malmö or Norrköping. Enslaved persons were also involved in producing other major colonial imports to Sweden during the eighteenth and nineteenth centuries, for example, coffee and cotton products. During the eighteenth century, Swedish herring from the Gothenburg county was exported to plantations in the Americas. Around the same time, Sweden's largest export, iron, played a major role in the transatlantic and colonial plantation economies to produce voyage iron, guns, shackles, chains, hoes, and machetes. As late as 1922, according to a report from the Swedish Ministry of Agriculture, "colonial goods" (kolonialvaror) such as coffee, spices, and cotton materials were among the most common wholesale goods in the country (Naum and Nordin 2013, ch 4 and 13; Evans and Rydén 2007; Rönnbäck 2007; Müller 2004; Government of Sweden 2008a, p. 95; Government of Sweden 1922, p. 14).

Another example of Sweden's involvement in the international racial ordering of the colonial era is its small overseas colony in the Caribbean, the island of St Barthélemy, which it held for nearly a century 1784-1878. Until Sweden signed the act at the Congress of Vienna in 1815 and promised not to participate in any new importation of enslaved Africans - Gustavia was a significant free port in the Caribbean for ships with enslaved Africans in addition to ships with other colonial merchandise such as tobacco, sugar, coffee, and rum (Pålsson 2016, pp. 61, 65-66, 224-5; Kern 2004). In June 1787 alone, 159 ships arrived and 160 ships left the island, out of 1033 and 1082 ships, respectively, for that year (Pålsson 2016, p. 61). Around 1804-1805, Gustavia was among the most prominent "slave ports" in the Caribbean with approximately 20 ships with an entire cargo of enslaved Africans, out of altogether 1800 vessels, entering annually (Pålsson 2016, p. 62; Weiss 2016, p. 138). As a free trade zone under a militarily neutral Swedish flag, the island became a (semi-)cosmopolitan, multinational, multiethnic, and multireligious haven for white entrepreneurs from across Europe, North America, and other islands in the Caribbean. According to Le Code de lois de la Martinique [The Code of Laws of Martinique] — which was applied on St Barthélemy and based on the French Code Noir-race determined rights. White people on the island enjoyed equal basic rights and freedoms and could become, if they were not already, naturalized Swedish subjects. "Free colored"-who in a less governmentally controlled free port like Gustavia had more opportunities than in most other places in the Caribbean - could in principle become Swedish citizens too, but - be they "negroes" or "mulattoes" with the same colour as white Europeans-not enjoy equal 
rights. For example, though they had some rights such as the right to own some forms of business, land, and other property, they initially had no voting rights under the Swedish flag. However, after a petition campaign in 1821, and the Swedish authorities wanting to avoid long term anything like the Haitian revolution, the free coloured received severely limited voting rights. They were also due flagellation if assaulting white persons and relegated to segregated housing quarters. Enslaved persons had no rights, were by law the private property of their owners, and subjected to such practices as being punished with death, hot iron torture or 150 lashes and the loss of an ear if they tried to escape (Weiss 2013, 2016, pp. 175-180; Pålsson 2016, pp. 68-9, 78-83, 2017, pp. 323-4; Wilson 2010).

Ideas such as that Sweden as a nation was part of a superior European civilization, that this superiority was due to innate qualities of its people, and that white ethnic Swedes had the right to colonize, dominate, and discriminate against "uncivilized" or less "civilized" peoples — have not least been prominent in Sweden's relationship to its own indigenous peoples, the Saami, and their lands in the northern parts of Scandinavia, Sápmi (e.g., Lundmark 2002, 2008). Although the inferiorizing and colonization of the Saami and Sápmi had been going on for centuries, it was accentuated during the nineteenth century. From then, it was characteristic of political and public discourse in Sweden to assume that white ethnic Swedes were at a "higher," more developed, stage of civilization and Saami peoples at a "lower," more primitive, stage. In the parliamentary discourse of nineteenth-century Sweden, it was often assumed that although it was natural that the Saami-whether they were nomadic or permanent residents, hunting, fishing, reindeer herding or trading for a living - should give way to state power, settlers, agriculture, and a higher civilization and one day would die out, it was a duty to protect them against this for as long as possible. Toward the end of the century, it also became popular to assume that the cultural differences between majority Swedes and the Saami were due to race, and in the beginning of the twentieth century, a racially, culturally, and occupationally segregating "Lapps shall be Lapps"-politics was in effect (Lundmark 2002, pp. 12-14, 31-43, 63-65). According to this politics, the exposure of the Saami to civilization through education, residential housing, and other means should be limited as they by nature were unfit for it. The state was also to actively retain their nomadic reindeer herding lifestyle - which their diverse lifestyles now were reduced to - in mountain areas that were unsuited for agriculture and foresting. It was not until the 1930s and 1940s, with growing doubts about the future of reindeer herding and when overt references to race fell into disrepute, that this politics of segregation slowly began to change (Lundmark 2002, pp. 67-121, 147-150, 158-159; Lundmark 2008, pp. 180-184, 208-213).

In the decades immediately prior to WWII, typical colonial era racial views of white superiority and non-white inferiority were prevalent in Sweden and actively promoted by the state. For instance, pre-WWII school books - and also post-WWII school books, though less explicitly - routinely referred to "lower" and "higher" races, "us" when describing the European conquest of Africa, Africans as savages without history, Europeans as bringing the blessings of civilization to humanity, Europe as the epitome of historical evolution, and the rest of humanity as on lower stages of development (Palmberg 2009, pp. 37-38). Before the war, it was commonplace in Swedish culture at large to portray Africans in overt racial stereotypes as at a lower stage of human development, primitive, childlike, and ridiculous (McEachrane 2001; Fornäs 2004; 
Palmberg 2009). Census classifications during the interwar period were racially motivated to demographically distinguish ethnic Swedes from "foreign races" such as Lapps, Finns, gypsies, and Jews (Rogers and Nelson 2003, pp. 61-79). The Swedish Aliens Act of 1927 stated that the purity of the Nordic race had "a value which can hardly be exaggerated," that it was essential to control the immigration of people "not suited to become a part of Sweden's population," and after 1938, the Swedish Immigration Office saw it fit to mark the passport of Jewish refugees with a "J" stamp, referred to them as "non-Aryans" and argued against a proposed law to liberalize the definition of a political refugee on the grounds that Swedes are unused to numerous foreigners in their midst and are inclined to be disturbed by them (Nordlund 2000, pp. 178-179; Kvist 2000).

Pre-WWII, the "racial hygiene" of the nation was a theme in Swedish politics. In 1921, the Swedish Parliament voted for the establishment of a state institute for race biology and eugenics. The institute studied the race biology of the population and promoted its conservation and improvement through sterilization and other eugenics programs. Its first two major publications were The Racial Characteristics of the Swedish Nation (1926), for an international scientific audience, and a pop-scientific version in Swedish that was well received by the public and press, Svensk raskunskap (Swedish race knowledge, 1927). These books showcased a survey of the height, skull shape, eye, hair, and skin color of about 50,000 persons, replete with illustrations and descriptions of the racial makeup of Sweden according to categories that were popular at the time. Majority ethnic Swedes were described as a superior Nordic race, minority Finns belonged to an inferior East Baltic/Slavic stock, the minority Saami's in the North were the most inferior of white Europeans, whereas the Roma people in the country belonged to another inferior race altogether (Blomqvist 2017; Schall 2012; Kjellman 2013; Hyatt 1997). In an article from 1928 in the journal The Eugenics Review, the first Director of the institute, Herman Lundborg, made the case that the "eugenical viewpoint must be given due regard, as we cannot afford to throw away the extremely valuable asset of good human stock" (Lundborg 1928, p. 291). "The good racial qualities which we have inherited through the generosity of Nature, have nowhere failed to evidence themselves," he writes lauding the colonial expansion of Europe, the "Swede, as well as the member of the other Scandinavian nations, is everywhere a welcome stranger. He becomes the pioneer, and as a rule, lays the foundation of a solid, organized state" (ibid).

During the 1930s and 1940s, when most Swedish eugenics was performed, its discourse shifted from a racial to a social-productive categorization of groups - such as the mentally defective, epileptics, and "travelers" (Tattare) - that should be sterilized for the genetic well-being of the nation. A new generation of medical and biological researchers questioned the previous messages spread by Swedish eugenics. Among them were Gunnar Dahlberg (1893-1956), who in 1935 succeeded a then retired Herman Lundborg at what now was called the Swedish State Institute of Human Genetics and Race Biology. Dahlberg's view on race, as expressed in a 1942 journal article "An Analysis of the Conception of Race and a New Method of Distinguishing Races," was more moderate than his predecessor's as he did not believe in discrete racial types as Lundborg had and doubted that there was any substantial racial difference between majority ethnic Swedes and Saami people, although he did not doubt that white Europeans and black Africans belonged to different races. Dahlberg 
contributed to the first two UNESCO statements on race- by commenting on a draft of the first and co-drafting the second - and also contributed to the UNESCO campaign against racism in the 1950s. After the revelations of the horrifying atrocities of the Nazi regime in the mid-1940s, Sweden dismissed any similarities between Swedish eugenics and German race doctrines. Eugenic sterilization reached its climax in Sweden during the period 1943-1949 (Tydén 2002, 2010, pp. 367, 371-372; Spektorowski and IreniSaban 2011; Dahlberg 1942).

\section{Sweden's Post-WWII Relationship to Race, Colonialism, and Human Rights}

During and after WWII, Sweden's state politics of race shifted. Soon after WWII, Sweden rose to prominence as an international champion for universal human rights. One of the chief ideologues of the Swedish Social Democrats, Alva Myrdal, took up a post as the Director of the UN Department of Social Affairs in New York in 1948 (Hirdman 2006, p. 276). Her husband, Gunnar Myrdal - a former Swedish minister and author of the influential An American Dilemma: The Negro Problem and Modern Democracy (1944) - became the first Executive-Secretary of the UN Economic Commission for Europe (1947-1957) (Barber 2008). Another former Swedish minister, Dag Hammarskjöld, became the second Secretary General 1953-1961 of the UN and remains a major symbol of it. Today, Sweden is the world's largest donor to humanitarian UN bodies, second largest donor to the UN Development Programme and third largest donor to the United Nations High Commissioner for Human Rights (OHCHR) (Government Offices of Sweden 2016). According to the UN Human Development Report 2016, though Sweden now ranks number 14 in the world on the UN Human Development and Gender Inequality indexes, it still receives more refugees per capita than any other European country (Jahan 2016).

Sweden's anticolonialism took off around 1960 when it made a decisive shift from previously being procolonial to speaking up against colonialism and Apartheid in the General Assembly (Huldt 1974). From then on until the early 1990s, Sweden played a major international role in financial and logistical support to the ANC and other liberation movements in Southern Africa. During the 1960s and 1970s, Sweden actively supported the development and self-determination of newly independent states. For example, it supported the Third World state-led Non-Alignment Movement and its decolonial initiative the New International Economic Order-which was supposed to lead to greater postcolonial self-determination, including a fairer distribution of power within international financial, trade, and development institutions. An important part of Sweden's post-WWII anticolonial and decolonial role was the state as well as international view of the country as without a colonial past or present and its overall nonpartisan neutrality in international affairs (Pierre 2016; Hilson 2008; Ekman Jørgensen 2008, p. 53; Sellström 1999, 2003; Ottosson 2003, pp. 34-35; Engh 2009; Ottosson 2003, p. 34; Agius 2006, pp. 113-114). As late as 2008, the Swedish government stated that "Sweden's lack of a colonial past in Africa" was among the factors that makes Sweden particularly suited to influence and cooperate with Africa (Government of Sweden 2007b, p. 67). 
In general, post-WWII Swedish state politics has excluded the country from the history of European colonialism and denied the relevance of race in shaping the organization of Swedish nationhood, society, and its place in the world. This Swedish post-WWII ethos was invoked in a 1965 Christmas speech by Olof Palme - one of its most prominent symbols, especially during his time as Prime Minister (1969-1976, 1982-1986): "Democracy is firmly rooted in this country. We respect the fundamental freedoms and rights. Murky racial theories have never found a foothold here. We like to see ourselves as open-minded and tolerant" (Palme 1968, p. 64, my translation). In the speech, Palme went on to say that "it is not that simple" as Swedes may harbor some prejudice in encounters with a growing immigrant population (ibid). It is in "our everyday lives", he stated, that we can show whether our ideal and principle of internationalism is real, and ended with a cosmopolitan vision of the nation:

Immigrants in Sweden can in a sense be said to herald a new age. They want to become part of our community and we must in turn seek our way out into a wider community across borders. The world comes to us and we need to get out into the world. (ibid, pp. 66, 67-68)

Such internationalism did not include discussions of any possible reckoning with a structuring force of race and colonialism in Sweden and its place in the world.

The general contention in Parliament during the 1960s, when racial discrimination first became a topic for debate, was that most Swedes rejected racial discrimination, that there was no need for laws prohibiting racial discrimination, and that the most effective measure against it was education. A public inquiry was issued in 1968 into whether Sweden needed to change its laws to accommodate the ICERD (Government of Sweden 1968, pp. 12-16). The Inquiry, which later resulted in a successful bill, proposed some new legal provisions against racial hate speech and racial discrimination in public facilities and services such as theaters and restaurants. However, no protections were proposed for the labor market. The Committee behind the Inquiry argued that there was no scientific evidence that racial discrimination was a social problem in Sweden. It also found the idea of laws that would regulate the labor market questionable - at least in part due to a Swedish model under which labor market partners have the right to enter into free contract agreements without interference of the state in the form of legislation - and suggested that trade unions should and would be prepared to combat racial discrimination if need be (ibid, pp. 66-68 and 78-79; Carlson 2016, pp. 142, 144-145, 159).

Sweden's first state party report to the UN Committee for the Elimination of Racial Discrimination (CERD) in 1973 affirmed that except for the prohibition of racial hate speech and racial discrimination in public facilities and services, laws against racial discrimination were unnecessary in Sweden since such discrimination already contradicted the fundamental principles of Swedish law. The report ended with a proclamation that a very large majority of the Swedish population are convinced that all people should be treated equally regardless of gender, race, ethnicity, or nationality; that the ideal and spirit of the ICERD enjoyed very strong support in Sweden; and that therefore no further legislation against racial discrimination was needed. It was not until 1994, after 20 years of criticism from the UN, that Sweden at all banned racial discrimination on the labor market (Lappalainen 2005, pp. 115-116). 


\section{Should the Term Race Be Eliminated?}

Sweden's latest state party report to CERD (submitted January 2017) follows a similar post-WWII line in supporting the exclusion of the term race from Sweden's antidiscrimination law, not recognizing structural racial discrimination as such nor the enduring relevance of European colonialism to respecting universal human rights in Sweden.

Sweden is among the few countries in the world that has eliminated the term race from its antidiscrimination law. In the Discrimination Act from 2009, the term is replaced with a broad definition of ethnicity as "national or ethnic origin, skin colour or other similar circumstance" (Government of Sweden 2008b). In its Concluding Observations from 2013 (on the combined 19th to 21st periodic reports of Sweden), CERD notes that deleting the term race "may lead to difficulties with the qualification and processing of complaints of racial discrimination thus hindering the access to justice for victims" (CERD 2013, p. 2). In response to this concern, the most recent Swedish state party report reiterates an argument in the 2007 Government Bill behind the new act, that "all people belong to the same race: the human race" and that continuing to use the word race "might legitimise racist assumptions and confirm race as an existing category" (Government of Sweden 2017, art. 25 p. 6; 2007a, b). ${ }^{2}$ Furthermore, it denies that the actual protection against discrimination has been watered down since the broad definition of ethnicity includes,

unfounded assumptions of "race", attitudes based on sweeping references to perceptions of the characteristics, appearance or background of "immigrants" being used to justify an approach, or where someone in general justifies discriminatory action with derogatory terms about people with a foreign or Swedish background. (Government of Sweden 2017)

Here it should be pointed out — which CERD does not - that the omission of the term race from Sweden's antidiscrimination law has a broader significance than for the possibility to protect against, report, and obtain redress for individual instances of discrimination. It also acts as a more general political norm for the kinds of discrimination to be recognized in society and how. For implementing the ICERD (and the DDPA), this is key since beyond protecting against individual instances of discrimination the ICERD (and the DDPA) more broadly requires states to protect against structural discrimination.

What is more, Sweden's elimination of the term race seems to be based on misconceptions of its nature. Already the four UNESCO statements on race (1950, 1951, 1964, and 1967) asserted that however laypeople or scientists may divide people into races, there is no evidence that these divisions represent discrete categories with definitive boundaries, genetic homogeneity, or innate psychological differences (UNESCO 1969). However, the UNESCO statements did not categorically dismiss race. The first Statement was accompanied by a document entitled What Is Race? which explained that, "Races share a general tendency to produce certain physical traits" and that these traits include "hair, eyes, head shape, physique, etc" (Reardon

\footnotetext{
${ }^{2}$ A Public Inquiry published in 2015 suggests that "race" be replaced in other Swedish law such as the Criminal Code and the Freedom of Press Act with "notions of race" (Government of Sweden 2015).
} 
2005 , p. 48). In contemporary philosophy, "racial eliminativism" - the idea that the term race ought to be eliminated since it lacks biological foundation - is generally dismissed as untenable. The main reasons being that the term race can be given meaning without reference to (psycho)biological essences - for example, by referring to visible physical features and a common ancestry in a distinctive geographic location - race is too socially significant to be eliminated and it still is debated whether race remains a meaningful category in population genetics (Taylor 2004, 2013; Zack 2017; Hardimon 2017a, b). In everyday parlance, racially ascriptive words like white or East Asian may be used without presuming the existence of innate psychological differences or discrete human populations. It makes perfect sense to speak of someone as "a white adolescent male about 1.80 metres tall" without presupposing the existence of psychobiological or otherwise biologically discrete populations. On a structural level, it is possible to refer to, say, the employment and housing situations of "white Swedes," "people of colour," or "people of African descent" on the basis of visible physical traits and geographical ancestry alone and without assuming that these are any (psycho) biologically discrete populations.

It is also crucial to understand the nature of racial discrimination-especially its structural dimensions - that we do not reduce it to beliefs in discrete (psycho)biological populations. Even if beliefs in discrete (psycho)biological populations may be socially prevalent — at least in principle — people may discriminate based on race while holding no particular or less certain beliefs about any innate connections between race and behavior. For example, a person may find that people of colour in general have alien and inferior mores and therefore discriminate against them - say, in situations of hiring, professional collaboration, or promotion - but without believing that such differences are innate. As implicit bias research on race demonstrates, having a socially/culturally derived imagination that allows one to, say, perceive black men as prone to violence may make one act accordingly while explicitly and sincerely rejecting that black men are prone to violence (e.g., Eberhardt 2005; Powell and Godsil 2011; Jolls and Sunstein 2006). Without any particular psychobiological assumptions, a property owner may discriminate against black people or Roma as possible tenants in fear that they could devalue the property by making it less attractive on the market. At a broad structural level, white parents may contribute to racial segregation merely by wanting to send their kids to schools conducive to high educational achievement (where the majority of students happen to be white) and keep them away from those that impede educational achievement (where the majority of students happen to be people of colour).

Regarding the view that race can be replaced by a broad definition of ethnicity without anything being lost - this too may mislead. While it seems fair to say that the term race at least singles out rough physical traits and geographical ancestry, it seems equally fair to say that the term ethnicity typically does not and that it at least singles out cultural groups (cf., e.g., Valdez and Golash-Boza 2017; Omi and Winant 2015; Mills 1998; Alcoff 2006). For this reason, discriminating against someone, say, by denying them a job because they are black generally is not the same as discriminating against their ethnicity. The person's ethnicity may be unknown to those who discriminate. She or he may be Bamileke from Cameroon or part Bamileke and part ethnic Swede or adopted as an infant from Cameroon by two ethnic Swedes and therefore selfidentify as ethnic Swede. Saying that someone is, say, black, white, or East Asian is not the same as pointing out their ethnicity, and it would be confusing to speak of black, 
white, or East Asian people as ethnic groups. Not only because their ethnic belonging may be undecided or various, but because insisting on speaking of them as such seems to suppose that they have a culture in common (which if nothing else is the kind of thinking that eliminating the term race was supposed to undermine in the first place).

To be fair, though, the broad definition of ethnicity in the Discrimination Act distinguishes "national or ethnic origin" from race-which is replaced by "skin colour or other similar circumstance". Yet, discrimination due to race-in terms of physical traits and geographical ancestry - is not merely on the basis of skin color and neither do designations such as black, non-white, and East Asian merely refer to skin colour. It is not on the basis of skin color per se that East Asians are discriminated against as many East Asians may be lighter than many white Europeans. When speaking of people as black, white, and so on, we are not referring to their skin tone per se. Typically, such terms refer more generally to people's appearances and ancestries (where skin tone may or may not be a decisive factor). Thus, either "skin colour" is taken literally which will render it socially senseless — especially in an antidiscrimination act—or it refers to race.

\section{Structural Racial Discrimination in Sweden?}

Central to the problem of Sweden's elimination of the term race is that the state does not recognize, monitor, or address structural racial discrimination even as a possible universal human rights issue. To this, the amount of people of colour in Sweden should not be decisive. Still, the growing number of people of colour in the country makes the problem even more pertinent. Although rough estimates of racial groups may currently be gleaned from available data on people's country of birth and citizenship, this will not be possible in a future that already is here with a growing amount of members of society who have third- and fourth-generation, etc., immigrant backgrounds. According to the official census bureau Statistics Sweden, immigrants today make up about $17 \%$ of the population, $9 \%$ of whom are born outside Europe, and the number of immigrants to Sweden - not to mention their descendants - are expected to rise in the future (Statistics Sweden 2016, pp. 22, 31). This can be compared to the USA, which in 2015 had an immigrant population of 13.2\% (United States Census Bureau 2015). In Sweden, immigrants are especially concentrated to the major cities - the three largest cities have around 15\% non-European immigrants alone (Statistics Sweden 2016, p. 28).

Yet, neither in, for instance, the recent state party report to Sweden, the current Government's national plan against racism since 2016 nor in the work of the Equality Ombudsman (DO) can one find as much as any mention of possible human rights disparities between people who visibly are of European descent (white people) and people who visibly are of non-European descent (people of colour) or whether the latter may be particularly vulnerable to discrimination in Sweden. The report mentions that ethnicity is the second most common ground for discrimination (after disability) in complaints received by the Equality Ombudsman (DO) - which is tasked with monitoring compliance with the Discrimination Act-but makes no further distinctions regarding "ethnic groups" (Government of Sweden 2017, p. 5). Instead of considering how Swedish nationhood may have been shaped by racial distinctions and a history of European colonialism and what this may mean with respect to universal human 
rights - the report seems to position Sweden as an exception to such histories, constitutionally inclusive and internationalist:

In the National plan [against racism], the Government asserts that throughout history Sweden has been a country in which a multitude of viewpoints, opinions and perspectives have been expressed and have coexisted. This means that Swedishness is the sum of a number of different parts. Saami, Afro-Swedish, Roma, Muslim and Jewish, along with many other components, are all part of what Swedishness is. (ibid, p. 10)

The recent national plan against racism as well as the state party report to CERD mentions housing segregation as a problem and a new long-term reform program that will run from 2017 to 2025 to tackle it - but no mention of whether it is a form of racial segregation between white and non-white members of society (Government of Sweden 2017 , p. 15). Though, from available studies it seems clear that residents with a nonEuropean background - and especially immigrants from Africa and the Middle Easttend to live in segregated low-income neighborhoods with other immigrants (Marcińczak et al. 2015; Aldén and Hammarstedt 2015). The three largest cities in Sweden-Stockholm, Gothenburg, and Malmö-are today as segregated as Los Angeles in the USA (Östh et al. 2014). In Sweden too, neighbourhoods with increasing numbers of non-white residents have tipping points that result in "white flight" (Aldén et al. 2015). And as in many other countries, among the results of urban segregation in Sweden are social stigma, feelings of hopelessness, growing social unrest and violence, and increasingly segregated primary schools with a strong effect on educational performance (Malmberg et al. 2013; Nationella operativa avdelningen 2015; Vallström 2015; Andersson et al. 2010).

There also seems to be reason to consider the possibility of recurrent racial discrimination against people of colour in employment in Sweden. For example, the unemployment rate of immigrants in Sweden with a non-European background is about four times that of natives (OECD 2015, pp. 310, 313). For Africans, it is five times (Aldén and Hammarstedt 2014, p. 11). This is despite that "Sub-Saharan Africans" in Sweden, according to a recent cross-European minority and discrimination survey by the European Agency for Fundamental Rights, may on average be more highly educated than the general population (FRA 2017, p. 89). Among those who neither work nor study, people from Africa and Asia are overrepresented (Government of Sweden 2013, pp. 15, 94 95). Immigrants from other European countries are about as likely to find jobs that match their level of education as native-born Swedes - whereas immigrants from nonEuropean countries (and especially those who are from Africa and Asia) are highly unlikely to do so (ibid, p. 16). In contrast to non-European immigrants who came to Sweden as children and have received their highest education there, childhood immigrants from Western, Central, and Eastern Europe do not receive lower pay or otherwise lower returns relative to their education than native Swedes (Katz and Östberg 2013, p. 27). "Sub-Saharan Africans" living in Sweden report among the highest incidents of workplace discrimination across the EU (17\% in the last 12 months) (FRA 2017, p. 36).

The state party report points out that "Afrophobic" hate crimes are by far the most prevalent of any category and that Afrophobia/anti-black racism is an extensive social problem (Government of Sweden 2017, pp. 28-31, 40-42). The Swedish National 
Council for Crime Prevention recognizes Afrophobic hate crimes as a category, and the current Swedish government has put some measures in place to combat Afrophobia such as tasking the Equality Ombudsman with carrying out awareness-raising initiatives on the subject (National Council for Crime Prevention 2017; Government of Sweden 2017, §34 p. 9). Still, there is no mention of Afrophobia as a form of racial discrimination and no reference to race or racial distinctions as such in relation to it.

Exclusively using terms like ethnicity, national origin, immigrant background, skin color and other similar circumstance when speaking of societal patterns of discrimination against people who visibly are of non-European descent may miss how and why such people can be discriminated against. For example, insisting that it is the ethnicity of people living in Sweden who visibly are of non-European descent that is the reason for their discrimination, may not be able to account for discriminating situations where their ethnicity - whether they are, say, Tigrinyan Eritrean Swedish, German, Irish American, or Miao from China - may be unknown or irrelevant or any discriminating patterns where merely pointing out that some people have foreign ethnicities seems insufficient. Similar things may be said of national origin or immigrant background. And, again, skin colour, when taken literally, neglects other visual features and will make little social sense as a ground of discrimination. Even when understood as a symbol for physical appearance more generally, it may only make sense as a ground of discrimination in conjunction with notions of geographical descent.

In addition, exclusively using terms like ethnicity, national origin, immigrant background, skin colour, and other similar circumstance may impede transnational comparisons of discrimination against people who visibly are of non-European descent. For example, how to make sense of such data as that across the EU people of non-European descent - in particular people of African, North African, or Middle Eastern originseem to suffer significant discrimination in employment whereas white European immigrants commonly do not (OECD 2013, pp. 209-210). Or if, why, and how Sweden may display similar patterns of discrimination against people who visibly are of non-European descent as in former European colonies. For example, why and how it could be the case that if the most discriminated minorities across Europe tend to be Roma and people of African (including North African) descent, across former European settler colonies in the Americas, they tend to be indigenous peoples and people of African descent (FRA 2017; Hernandez 2013, pp. 73-101; Telles 2014).

To be fair, though the state of Sweden does not refer to race or racial distinctions for antidiscrimination purposes nor describe structural racial discrimination as such - it is not without any recognition of structural racism whatsoever. This has been true at least since 2005-2006 when a massive series of 15 state public reports on grounds of ethnic or religious structural discrimination was published (e.g., de los Reyes and Kamali 2005; Lappalainen 2005). Yet, besides not making any references to race and racial distinctions, there seems to be a tendency to reduce structural racism to matters of belief and attitudes. In the national plan against racism from 2016, the Government declares that it is important to recognize the existence of structural racism. The plan describes it as widespread conscious or unconscious beliefs about ethnic groups, which lead to that members of such groups have different access to rights and opportunities, and suggests that individual cases of discrimination or hate crime are not isolated events, but part of a larger context (Government of Sweden 2016, p. 11). Similarly, the National plan defines Afrophobia as "ideologies, beliefs or values that express hostility against 
Afro-Swedes..." (ibid, p. 11). Such a definition seems to neglect how society may be organized - by design or not - in ways that lead to recurring and compounded disadvantages and unequal access to rights for people of African descent, for instance, de facto segregation and unequal access to basic resources such as education, the portrayal (or lack of portrayal) in educational material of the histories and current situations of Africans/people of African descent, or lack of accumulated opportunities, power, and influence in society.

\section{The Coloniality of Race in Sweden?}

Beyond the purpose of accurately describing, monitoring, and addressing possible structural racial discrimination in Sweden and placing it in a comparative transnational perspective - an additional reason for using the term race with respect to universal human rights is what may be called the coloniality of race (cf., e.g., Quijano 2000; Ndlovu-Gatsheni 2013). That is, any possible distinctions, discriminating structures and moral relationships between white people, people of colour, and indigenous peoples, and developed and developing countries, that are consequences or at least continuations of the colonial era. Exclusively using terms like ethnicity, national origin, immigrant background, skin colour and other similar circumstance may make it seem like race and structural racial discrimination also is irrelevant to Sweden in the sense that the country did not participate in nor contribute to the structural racial discrimination of the colonial era, bears no responsibility for it, and is not implicated by any of its legacies with respect to universal human rights. It may exclude or hinder such questions as whether, if at all, the state of Sweden has any special responsibilities regarding how its organization and practices as a European nation-state has led to racial discrimination and undermined human rights. Or whether, if at all, a racially discriminating international order of European colonialism today is perpetuated by Sweden and its relationship to other countries.

Two of CERD's general recommendations for how to interpret the ICERD - General Recommendations 28 and 33 - call on states to take the DDPA into account when implementing the ICERD, disseminate the DDPA, and include in their periodic reports information on measures they have taken to implement the DDPA (OHCHR 2002, 2009). Concomitantly, CERD's latest Concluding Observations of Sweden from 2013 recommends that the state gives effect to the DDPA when implementing the ICERD and that its next periodic report includes information on measures taken to implement the DDPA (CERD 2013, §23 pp. 7-8).

Sweden's response to this in its latest report to CERD is to refer to its national action plan to combat Afrophobia, antiziganism, Islamophobia, and racism against Saami people, and its tasking of the state agency the Living History Forum to, among other things, carry out "a major education initiative on different forms of racism and intolerance in history and today, to run until 2019" (Government of Sweden 2017, $\S 43)$. However, the national action plan itself does not mention the DDPA nor colonialism or racial discrimination as such (Government of Sweden 2016). Nonetheless, in the ongoing fulfillment of its task, the Living History Forum has taken some steps toward recognizing the relevance of colonialism to Sweden. Its website describes Sweden's ongoing relationship to Sápmi (the Northern part of Scandinavia inhabited by 
the only recognized indigenous peoples of Europe, the Sami) as a colonial one, and a piece written by myself places Afrophobia/anti-black racism in the context of European colonialism and the enslavement of Africans (Brännlund and Drugge 2016; McEachrane 2016). A review report from the Forum on historical research on racism in Sweden links it (in particular anti-black racism) to an era of European colonialismalbeit without implications to universal human rights as indicated by the DDPA (Ericsson 2016, pp. 81-82, 139, 150-152).

Overall, it seems fair to say that thus far Sweden's possible role in and responsibilities for the national and international ramifications of colonialism to structural racial discrimination, as recognized by the DDPA, largely remain unrecognized by the state. Though the Swedish state recently has taken some steps toward exploring its participation in European colonialism, it has yet to recognize structural racial discrimination as such even as a possibility within its borders. Let alone the possibility that there may be structural racial discrimination and inequities within Sweden's borders as well as in its relationship to the outside world and in other parts of the world that are results and continuations of a colonial era that Sweden participated in, benefited from, and bears some responsibility for.

However, there are two events on the horizon that could change this. One is that the Swedish Saami Parliament together with the Equality Ombudsman are developing a Truth Commission to investigate the Swedish state's abuse of the Saami and their human rights and to propose appropriate compensatory and forward-looking measures to correct the historical trauma (Saami Parliament of Sweden 2017). Just to mention one indicator of the current human rights situation of the Saami-according to a 2016 knowledge compilation by the Saami Parliament on the mental health of Swedish Saami, half of young Saami women have considered suicide, one in three young reindeer herding Saami have seriously considered or have planned to commit suicide, and about two out of five male reindeer herders seem to suffer from clinical anxiety disorders (Saami Parliament of Sweden 2016, p. 6). In a 2015 report that the Saami Parliament submitted to the UN Special Rapporteur on the Rights of Indigenous Peoples, colonialism is mentioned 55 times in 75 pages. Among other things, the report recommends a Truth Commission that would "fully address and bring redress for all colonial and structural roots of discrimination and Indigenous Rights violations that the Sami Indigenous People in Sweden have endured and continue to unjustly suffer from" (Saami Parliament of Sweden 2015, p. 4).

Unambiguously naming, recognizing, and addressing structural racial discrimination against the Saami probably needs to be part of this process. Although, today, the Saami are defined by Swedish and European law as an ethnic minority that is culturally distinct and has a history in the country (Council of Europe 1995). In addition, they are indigenous people to which rights to self-determination, cultural integrity, and land are central (ILO 1989; UN General Asembly (UNGA) 2007). They typically also are physically indistinguishable from white ethnic Swedes and not discriminated against based on features such as skin colour. Therefore, it may seem appropriate to speak of the discrimination Saami face as instances of ethnic rather than racial discrimination. On the other hand, historically, the Swedish Saami have been subjected to racial inferiorization and exclusion from a racially circumscribed Swedish nationhood. A part of the harm that has been done to them is to deny them equal human dignity and rights on the basis that they are innately inferior peoples with innately inferior cultures. 
This racial (or at least racialized) oppression of the Saami arguably is continuous with Sweden's and other European countries' historical understanding of, for instance, white European identity, nationhood, civilization, and human dignity; and their treatments of indigenous peoples and people of colour elsewhere (cf., e.g., Fur 2013).

The other event is that the 15 member states of the Caribbean Community (CARICOM) currently are calling on Sweden and other European states to-as the DDPA would have it - "take appropriate and effective measures to halt and reverse the lasting consequences" of such practices as slavery, the transatlantic slave trade, apartheid, and colonialism (OHCHR 2001, art. 102 p. 38). CARICOM is requesting that Sweden and other European states finance a 10-point CARICOM Reparatory Justice Program (CRJP) (CARICOM Reparations Commission 2014). Most of the measures included in the program are already recommended by the DDPA — such as an official apology for the crimes against humanity that were perpetrated in the region, debt relief, technology transfer, illiteracy eradication, an indigenous peoples' development program, and a program for the welcome return to Africa of descendants of enslaved Africans (OHCHR 2001). CARICOM has vowed to take Sweden and other European states to the International Court of Justice if they are unwilling to support the CRJP (CARICOM 2016).

For Sweden, CARICOM's demand for reparations is an opportunity to face up to and-if and where ever it may be due - take responsibility for its participation in a colonial order of racial discrimination and human rights violations. Though the state of Sweden never was a major colonial power compared to, say, Britain or France-its direct and indirect contributions to and material benefits from the enslavement of Africans and its institutionalized suppression of the rights of people of African descent on St Barthélemy speaks to ways in which Sweden too has both privileged and undermined human rights on the basis of race.

Acknowledgements I would like to thank the two anonymous reviewers, the Editor-in-Chief of this journal Professor Steven D Roper, Professor Paul C Taylor, Professor Stephen Small, Professor Nana Osei-Kofi, Paul Lappalainen, and Olúfẹmi O. Táíwò for their helpful comments on an earlier draft of this article.

Open Access This article is distributed under the terms of the Creative Commons Attribution 4.0 International License (http://creativecommons.org/licenses/by/4.0/), which permits unrestricted use, distribution, and reproduction in any medium, provided you give appropriate credit to the original author(s) and the source, provide a link to the Creative Commons license, and indicate if changes were made.

\section{References}

Agius C (2006) The Social Construction of Swedish Neutrality: Challenges to Swedish Identity and Neutrality. Manchester University Press, Manchester and New York

Alcoff LM (2006) Visible Identities: Race, Gender and the Self. Oxford University Press, Oxford and New York

Aldén L, Hammarstedt M (2014) Utrikes födda på den svenska arbetsmarknaden - en översikt och en internationell jämförelse. Survey report to the Social Democrats Research Commission Labour market reforms for jobs and welfare. Linnaeus University Centre for Labour Market and Discrimination Studies, Växjö

Aldén L, Hammarstedt M (2015) Boende med konsekvens - en ESO-rapport om etnisk bostadssegregation och arbetsmarknad. Report for the Swedish Ministry of Finance 2016:1. Elanders AB, Stockholm 
Aldén L, Hammarstedt M, Neuman E (2015) Ethnic Segregation, Tipping Behavior, and Native Residential Mobility. International Migration Review vol 49 no 1: 36-69

Andersson E, Östh J, Malmberg B (2010) Ethnic Segregation and Performance Inequality in the Swedish School System: A Regional Perspective. Environment and Planning A vol 42 no 11: 2674-2686

Barber WJ (2008) Gunnar Myrdal: An Intellectual Biography. Palgrave Macmillan, Basingstoke and New York

Blomqvist H (2017) Socialist patriotism, racism and antisemitism in the early Swedish labour movement, Patterns of Prejudice, 51:3-4: 318-334

Bonilla-Silva E (2000) This Is a White Country: The Racial Ideology of the Western Nations of the WorldSystem. Sociological Inquiry, vol 70 no 2: 188-214. doi: https://doi.org/10.1111/j.1475-682X.2000. tb00905.x

Bonilla-Silva E (2006) Racism without Racists: Colour-blind Racism and the Persistence of Racial Inequality in the United States, 2nd edn. Rowman and Littlefield, Lanham and Oxford

Brännlund I, Drugge A-L (2016) Kolonisation. Forum för levande historia, Stockholm. http://www. levandehistoria.se/fakta-fordjupning/olika-former-av-intolerans/rasism-mot-av-samer/kolonisation, accessed 20 March 2018

CARICOM (2016) Barbados PM Writes Britain on Reparation on Behalf of CARICOM. https://caricom. org/communications/view/barbados-pm-writes-britain-on-reparation-on-behalf-of-caricom, accessed 20 March 2018

CARICOM Reparations Commission (2014) 10-Point Reparation Plan. http://caricomreparations. org/caricom/caricoms-10-point-reparation-plan/, accessed 20 March 2018

Carlson L (2016) Addressing unlawful discrimination: The Swedish Journey. In: Carlson L, Globalization, Fragmentation, Labour and Employment Law: A Swedish Perspective. Iustus förlag, Uppsala, pp. 139160

CERD (1993) General Recommendation 14 on article 1, paragraph 1, of the Convention, http://tbinternet. ohchr.org/_layouts/treatybodyexternal/TBSearch.aspx?Lang=en\&TreatyID=6\&DocTypeID=11 accessed 19 March 2018

CERD (2013) Concluding observations on the combined nineteenth to twenty-first periodic reports of Sweden, adopted by the Committee at its eighty-third session (12-30 August 2013). Office of the High Commissioner for Human Rights, Geneva

Council of Europe (1995) Council of Europe's Framework Convention for the Protection of National Minorities, https://rm.coe.int/16800c10cf, accessed 19 March 2018

Dahlberg G (1942) An Analysis of the Conception of Race and a New Method of Distinguishing Races. Human Biology vol 14 no 3: 372-385

de los Reyes P, Kamali M (eds) (2005) Bortom Vi och Dom: Teoretiska reflektioner om makt, integration och strukturell diskriminering. SOU 2005:41. Edita Norstedts Tryckeri AB, Stockholm

DuBois WEB (2007) The World and Africa; Color and Democracy: Colonies and Peace. Oxford University Press, Oxford and New York

Eberhardt JL (2005) Imaging Race. American Psychologist vol 60 no 2: 181-190

Ekman Jørgensen T (2008) Transformations and Crises: The Left and the Nation in Denmark and Sweden, 1956-1980. Berghahn Books, New York and Oxford

Engh S (2009) The Conscience of the World? Swedish and Norwegian Provision of Development Aid. Itininerario vol 33 no 2: 65-82. doi: https://doi.org/10.1017/S0165115300003107

Ericsson M (2016) Historisk forskning om rasism och främlingsfientlighet i Sverige. Forum för levande historia, Stockholm

Evans C, Rydén G (2007) Baltic Iron in the Atlantic World in the Eighteenth Century. Brill, Leiden

Eze EC (ed) (1997) Race and the Enlightenment: A Reader. Blackwell, Cambridge MA

Fanon F (2004/1963) The Wretched of the Earth. Grove Press, New York

Fornäs J (2004) Moderna människor: Folkhemmet och jazzen. Stockholm: Nordstedts

FRA (2017) EU-MIDIS: European Union Minorities and Discrimination Survey. European Union Agency for Fundamental Rights, Vienna

Fur G (2013) Colonialism and Swedish History: Unthinkable Connections? In: Naum M, Nordin JM (eds) Scandinavian Colonialism and the Rise of Modernity: Small Time Agents in a Global Arena. Springer, New York and Heidelberg

Gilroy P (2005) Postcolonial Melancholia. Columbia University Press, New York and Chichester

Go J (2011) Patterns of Empire: The British and American Empires, 1688 to the Present. Cambridge University Press, Cambridge and New York

Go J (2016) Postcolonial Thought and Social Theory. Oxford University Press, Oxford and New York

Goldberg DT (2009) The Threat of Race. Blackwell Publishing, Malden and Oxford 
Government of Sweden (1922) Mellanhandssakkunniges betänkande angående olägenheterna vid mellanhandssystemet inom livsmedelshandeln SOU 1922: 20. Jordbruksdepartementet, Stockholm

Government of Sweden (1968) Lagstiftning mot rasdiskriminering, SOU 1968:68. Justitie Departementet. Esselte AB, Stockholm

Government of Sweden (2007a) Ett starkare skydd mot diskriminering. Regeringens proposition 2007/08:95. The Department of Integration and Gender Equality, Stockholm

Government of Sweden (2007b) Sverige och Afrika - en politik för gemensamma utmaningar och möjligheter. Regeringens skrivelse 2007/08

Government of Sweden (2008a) Delegationen för mänskliga rättigheter i Sverige: Rapporter från en mr verkstad SOU 2008:45. Edita Sverige AB, Stockholm

Government of Sweden (2008b) Discrimination Act, Swedish Code of Statutes. Ministry of Labor, Stockholm

Government of Sweden (2013) Vid arbetslivets gränser: Sysselsättning, matchning, barriärer 1974-2010. Parliamentary Social Insurance Investigation-S 2010: 04. Elanders AB, Stockholm

Government of Sweden (2015) Ett utvidgat straffrättsligt skydd för transpersoner m.m., SOU 2015:103. Elanders Sverige AB, Stockholm

Government of Sweden (2016) Samlat grepp mot rasism och hatbrott: Nationell plan mot rasism, liknande former av fientlighet och hatbrott. Ministry of Culture. Elanders, Stockholm

Government of Sweden (2017) Consideration of reports submitted by States parties under article 9 of the Convention. Twenty-second and twenty-third periodic reports of States parties due in 2016, CERD/C/ SWE/Q/19-2 (19 January 2017)

Government Offices of Sweden (2016) Sweden and the UN in Figures. http://www.government. se/government-policy/sweden-and-the-un/sweden-and-the-un-in-figures/, accessed 20 March 2018

Hannaford I (1996) Race: The History of an Idea in the West. John Hopkins University Press, Baltimore

Hardimon MO (2017a) Minimalist Biological Race. In: Zack N (ed) The Oxford Handbook of Philosophy and Race. Oxford UP, Oxford and New York, pp. 150-159

Hardimon MO (2017b) Rethinking Race: The Case for Deflationary Realism. Harvard University Press, Cambridge and London

Hernandez TK (2013) Racial Subordination in Latin America: The Role of the State, Customary Law and the New Civil rights Response. Cambridge UP, New York and Melbourne

Hilson M (2008) The Nordic Model: Scandinavia Since 1945. Reaktion Books Ltd, London

Hirdman Y (2006) Alva Myrdal: The Passionate Mind. Indiana UP, Bloomington and Indianapolis

Huldt B (1974) Sweden, the United Nations and Decolonization: A Study of Swedish Participation in the Fourth Committee of the General Assembly 1946-69. Lund Studies in International History 5. Esselte Studium, Lund

Hyatt S (1997) A Shared History of Shame: Sweden's Four Decade Policy of Forced Sterilization and the Eugenics Movement in the United States. Indiana International and Comparative Law Review 8: 475-503

ILO (1989) Indigenous and Tribal Peoples Convention, No. 169. International Labour Organization, Geneva. http:/www.ilo.org/dyn/normlex/en/f?p=NORMLEXPUB:12100:0::NO::P12100_ILO_CODE:C169, accessed 20 March 2018

Jackson Jr JP, Weidman NM (2004) Race, Racism, and Science: Social Impact and Interaction. ABC-CLIO, Santa Barbara

Jahan S (2016) UN Human Development Report 2016. UN Development Programme, New York

Jolls C, Sunstein CR (2006) The Law of Implicit Bias. California Law Review vol 94 no 4: 969-996

Katz K, Östberg T (2013) Unga invandrare - utbildning, löner och utbildningsavkastning. Rapport 2013: 6. IFAU - Institutet för arbetsmarknads- och utbildningspolitisk utvärdering, Uppsala

Kern HL (2004) Strategies of Legal Change: Great Britain, International Law, and the Abolition of the Transatlantic Slave Trade. J. Hist. Int'l L. 6233

Keskinen S, Tuori S, Irni S and Mulinari D (eds.) (2009) Complying with Colonialism: Gender, Race and Ethnicity in the Nordic Region. Routledge, New York

Kjellman U (2013) A Whiter Shade of Pale: Visuality and Race in the Work of the Swedish State Institute of Race Biology. Scandinavian Journal of History vol 38 no. 2180-201. doi: https://doi.org/10.1080 $/ 03468755.2013 .769458$

Kvist K (2000) A Study of Antisemitic Attitudes within Sweden's Wartime Utlänningsbyrån. The Journal of Holocaust Education vol 9 no 2: 199-211

Lappalainen P (2005) Det blågula glashuset: Strukturell diskriminering i Sverige, SOU 2005: 56. Elanders Gotab AB, Stockholm

Loftisdóttir K, Jensen L (eds.) (2012) Whiteness and Postcolonialism in the Nordic Region: Exceptionalism, Migrant Others and National Identities. Ashgate, Farnham and Burlington 
Lundborg H (1928) Race Biological Aspects of Some Problems of Population. The Eugenics Review vol 19 no 4

Lennart Lundmark (2002) "Lappen är ombytlig, ostadig och obekväm...": Svenska statens samepolitik i rasismens tidevarv. Norrlands Universitetsförlag, Umeå

Lundmark L (2008) Stulet Land: Svensk makt på samisk mark. Ordfront förlag, Stockholm

Malmberg B, Andersson E, Östh J (2013) Segregation and Urban Unrest in Sweden. Urban Geography vol 34 no 7: 1031-1046

Marcińczak, S Tammaru T, Strömgren M, Lindgren U (2015) Changing patterns of residential and workplace segregation in the Stockholm metropolitan area. Urban Geography vol 36 no 7: 969-992

Mbembe A (2017) Critique of Black Reason. Duke University Press, Durham

McEachrane M (2001) "Negrer och lokomotiv!": Primitivism och modernitet i Artur Lundkvists författarskap. In: McEachrane M, Faye L (eds) (2001) Sverige och de Andra: Postkoloniala perspektiv. Natur och Kultur, Stockholm

McEachrane M (2016) Afrofobins historia i Sverige. Forum för levande historia, Stockholm. http://www. levandehistoria.se/fakta-fordjupning/olika-former-av-intolerans/afrofobi/afrofobins-historia-i-sverige, accessed 20 March 2018

McEachrane M, Faye L (eds) (2001) Sverige och de Andra: Postkoloniala perspektiv. Natur och Kultur, Stockholm

McKittrick K (2015) Sylvia Wynter: On Being Human as Praxis. Duke University Press, Durham

Mills CW (1997) The Racial Contract. Cornell University Press, Ithaca and London

Mills CW (1998) Blackness Visible: Essays on Philosophy and Race. Cornell University Press, Ithaca and London

Mills CW (2003) White Supremacy as Sociopolitical System: A Philosophical Perspective. In: Doane A, Bonilla-Silva E (eds), White Out: The Continuing Significance of Racism. Routledge, New York and London

Mills CW (2017) White Ignorance. In: Black Rights/White Wrongs: The Critique of Racial Liberalism. Oxford University Press, New York

Müller L (2004) Kolonialprodukter i Sveriges handel och konsumtionskultur, 1700-1800. Historisk Tidskrift, Issue 2: $225-248$

National Council for Crime Prevention (2017) Reported hate crimes, http:/www.bra.se/bra-inenglish/home/crime-and-statistics/crime-statistics/reported-hate-crimes.html, accessed 19 March 2018

Nationella operativa avdelningen (2015) Utsatta områden—sociala risker, kollektiv förmåga och oönskade händelser. Underrättelse enheten, Stockholm

Naum M, Nordin JM (eds) (2013) Scandinavian Colonialism and the Rise of Modernity: Small Time Agents in a Global Arena. Springer, New York and Heidelberg

Ndlovu-Gatsheni SJ (2013) Empire, Global Coloniality and African Subjectivity. Berghahn Books, New York and Oxford

Nilsson D (2013) Sweden-Norway at the Berlin Conference 1884-1885: History, National Identity-making and Sweden's relations with Africa. Current African Issues 53. Nordiska Afrikainstitutet, Uppsala

Nordlund S (2000) “The War is Over-Now You Can Go Home!” Jewish Refugees and the Swedish Labour Market in the Shadow of the Holocaust. The Journal of Holocaust Education vol 9 no 2

Nováky G (1990) Handelskompanier och kompanihandel: Svenska Afrikakompaniet 1649-1663. En studie i feodal handel. Studica Historica Upsaliensia 159. Almqvist och Wiksell International, Stockholm

OECD (2013) International Migration Outlook 2013. OECD Publishing http://www.oecd-ilibrary.org/socialissues-migration-health/international-migration-outlook-2013_migr_outlook-2013-en, accessed 19 March 2018

OECD (2015) Indicators of Immigrant Integration 2015: Settling In. OECD Publishing, Paris, http://www. oecd.org/publications/indicators-of-immigrant-integration-2015-settling-in-9789264234024-en.htm, accessed 19 March 2018

Office of the United Nations High Commissioner for Human Rights (OHCHR) (1965) International Convention for the Elimination of All Forms of Racial Discrimination (ICERD), http://www.ohchr. org/EN/ProfessionalInterest/Pages/CERD.aspx, accessed 19 March 2018

OHCHR (1978) Declaration on Race and Racial Prejudice, http://www.ohchr. org/EN/ProfessionalInterest/Pages/RaceAndRacialPrejudice.aspx, accessed 20 March 2018

OHCHR (2001) The Durban Declaration and Programme of Action (DDPA), http://www.un. org/WCAR/durban.pdf, accessed 19 March 2018

OHCHR (2002) CERD General Recommendation 28 on the follow-up to the World Conference against Racism, Racial Discrimination, Xenophobia and Related Intolerance, http://binternet.ohchr.org/_ layouts/treatybodyexternal/TBSearch.aspx?TreatyID=6\&DocTypeID=11, accessed 19 March 2018 
OHCHR (2009) CERD General Recommendation 33-Follow-up to the Durban Review Conference, http://tbinternet.ohchr.org/_layouts/treatybodyexternal/TBSearch.aspx?TreatyID=6\&DocTypeID=11, accessed 19 March 2018

OHCHR (2011) CERD General Recommendation 34 adopted by the Committee-Racial discrimination against people of African descent, http://tbinternet.ohchr.org/_layouts/treatybodyexternal/TBSearch. aspx?TreatyID=6\&DocTypeID=11, accessed 19 March 2018

Omi, M and Winant, H (2015) Racial Formation in the United States. Third Edition. New and London: Routledge

Östh J, Clark WAV, Malmberg B (2014) Measuring the Scale of Segregation Using $k$-Nearest Neighbor Aggregates. Geographical Analysis: 1-16

Ottosson S (2003) Svensk självbild under kalla kriget: En studie av stats- och utrikesminstrarnas bild av Sverige 1950-1989. Utrikespolitiska Institutet, Stockholm

Palmberg M (2009) The Nordic Colonial Mind. In: Keskinen S et al. (eds) Complying with Colonialism: Gender, Race and Ethnicity in the Nordic Region. Routledge, New York

Palme O (1968) Politik är att vilja. Bokförlaget Prisma, Stockholm

Pålsson A (2016) Our Side of the Water: Political Culture in the Swedish colony of St Barthélemy 1800-1825. Stockholm Studies in History 106. Stockholm University, Stockholm

Pålsson A (2017) Smugglers before the Swedish throne: Political activity of free people of color in early nineteenth-century St Barthélemy. Atlantic Studies, 14:3: 318-335

Pierre J (ed) (2016) The Oxford Handbook of Swedish Politics. Oxford University Press, Oxford

Powell J, Godsil R (2011) Implicit Bias Insights as Preconditions to Structural Change. Poverty and Race vol 20 no 5: 3-6

Quijano A (2000) Coloniality of Power, Eurocentrism and Latin America. Nepantla: Views from South vol 1 no 3: $533-580$

Reardon J (2005) Race to the Finish: Identity and Governance in an Age of Genomics. Princeton UP, Princeton

Rogers J, Nelson MC (2003) "Lapps, finns, gypsies, jews, and idiots"? Modernity and the use of statistical categories in Sweden. Annales de démographie historique vol 1 no 105: 61-79

Rönnbäck K (2007) From extreme luxury to everyday commodity Sugar in Sweden, 17th to 20th centuries. Göteborg Papers in Economic History, No. 11: 1-31

Saami Parliament of Sweden (2015) Preparatory Report from the Sami Parliament in Sweden for the UN Special Rapporteur on the Rights of Indigenous Peoples, Ms Victoria Tauli-Corpuz, prior to her 2015 August visit to Sápmi and Sweden, https://www.sametinget.se/92639, accessed 20 March 2018

Saami Parliament of Sweden (2016) Kunskapssammanställning om samers psykosociala ohälsa. Sametinget, Kiruna

Saami Parliament of Sweden (2017) Behövs en sanningskommission? https://www.sametinget. se/sanningskommission, accessed 20 March 2018

Schall CE (2012) (Social) Democracy in the Blood? Civic and Ethnic Idioms of Nation and the Consolidation of Swedish Social Democratic Power, 1928-1932, Journal of Historical Sociology, vol 25 no 3: 440-474. doi: https://doi.org/10.1111/j.1467-6443.2012.01428.x

Sellström T (1999) Sweden and National Liberation in Southern Africa. Volume I: Formation of Popular Opinion 1950-1970. Nordiska afrikainstitutet, Uppsala

Sellström T (2003) Sweden and National Liberation in Southern Africa. Volume 1: Formation of a Popular Opinion 1950-1970. 2nd edn. Nordiska Afrikainstitutet, Uppsala

Shilliam R (2017) The Crisis of Europe and Colonial Amnesia: Freedom Struggles in the Atlantic Biotope. In: Go J, Lawson G (eds) Global Historical Sociology. Cambridge University Press, Cambridge and New York

Spektorowski A, Ireni-Saban L (2011) From 'race hygiene' to 'national-productivist hygiene'. Journal of Political Ideologies, 16(2): 169-193

Statistics Sweden (2016) Integration - establishment of foreign born persons in working life and in society. Demographic reports 2016:1. Statistics Sweden Forecast Institute, Stockholm

Taylor PC (2004) Race: A Philosophical Introduction. Polity Press, Cambridge

Taylor PC (2013) Bare Ontology and Social Death. Philosophical Papers vol 42 no 3: 371-391

Telles EE (2014) Pigmentocracies : Ethnicity, Race and Colour in Latin America. The University of North Carolina Press, Chapel Hill

Thornberry P (2016) The International Convention on the Elimination of All Forms of Racial Discrimination. Oxford University Press, Oxford and New York

Tydén M (2002) Från politik till praktik: De svenska steriliseringslagarna 1935-1975. Stockholm Studies in History -63 . Almqvist and Wiksell International, Stockholm 
Tydén M (2010) The Scandinavian States: Reformed Eugenics Applied. In: Bashford A, Levine P (eds), The Oxford Handbook of the History of Eugenics. Oxford University Press, Oxford and New York, pp. 363373

UN General Asembly (UNGA) (2007) United Nations Declaration on the Rights of Indigenous Peoples. GA 61/295. United Nations, New York City. http:/www.un.org/esa/socdev/unpfii/documents/DRIPS_en.pdf, accessed 20 March 2018

UNESCO (1969) Four Statements on the Race Question. COM.69/11.27/A. UNESCO, Paris

United States Census Bureau (2015) Place of Birth By Nativity and Citizenship Status: 2011-2015 American Community Survey, https://factfinder.census.gov/faces/tableservices/jsf/pages/productview.xhtml?pid= ACS_15_5YR_B05002\&prodType=table, accessed 22 June 2017

Valdez Z, Golash-Boza T (2017) U.S. racial and ethnic relations in the twenty-first century. Ethnic and Racial Studies, 40:13: 2181-2209

Vallström M (2015) Mörkade platser-stigmatisering och ryktesspridning I urbana utvecklingsområden. Centrum för flexibelt lärande_-Söderhamns kommun, Söderhamn

Weiss H (2013) A Divided Space: Subjects and Others in the Swedish West Indies during the late-Eighteenth Century. In: Rydén G (ed) Sweden in the Eighteenth-Century World: Provincial Cosmopolitans. Ashgate, Farnham and Burlington, pp. 275-297

Weiss H (ed) (2015) Ports of Globalisation, Places of Creolisation: Nordic Possessions in the Atlantic World During the Era of the Slave Trade. Brill, Leiden and Boston

Weiss H (2016) Slavhandel och slaveri under svensk flagg. Svenska litteratursällskapet i Finland, Helsingfors Wilson V (2010) Commerce in Disguise: War and Trade in the Caribbean Free Port of Gustavia, 1793-1815. Åbo Akademi University Press, Åbo

Wittgenstein L (2009) Philosophical Investigations (1e 1953). Blackwell Publishing, Malden and Oxford Zack N (ed) (2017) Oxford Handbook of Philosophy and Race. Oxford UP, New York 